\title{
BIO- AND MAGNETOSTRATIGRAPHY OF THE UPPERMOST CRETACEOUS AND LOWER TERTIARY STRATA OF NORTH DAKOTA
}

HARTMAN*, Joseph H., Energy \& Environmental Research Center, University of North Dakota, PO Box 9018, Grand Forks, ND 58202, U.S.A.; KIHM, Allen J., Department of Earth Sciences, Minot State University, Minot, ND 58707, U.S.A.

The uppermost Cretaceous (K) and Lower Tertiary (T) strata of the North Dakota portion of the Williston Basin contain significant geologic sections (Figure 1), including 1) the type area of the Fort Union Group; 2) the most complete record of the Cannonball Formation; and 3) the youngest Cretaceous (Fox Hills and Breien) and oldest Tertiary (Cannonball) marine strata in the interior of North America. Present studies have correlated these strata to the North America land mammal age biochronology and a current radiometric and polarity chronology. On the basis of palynomorphs, the Hell Creek-Ludlow formational contact is effectively isochronous and a near match to the $\mathrm{K} / \mathrm{T}$ boundary across western North Dakota. Planktic forams from the main body of the Cannonball Formation indicate the unit as lower but not basal Paleocene. The Cannonball Formation is correlated to a radiometric time scale on the basis of current planktonic foram zone age dates. Three tongues of the Cannonball Formation have been recognized. Radiometric dates and mammalian fossils suggest a Puercan age for the lowermost tongue, while the Boyce and Three V Tongues are probably of Torrejonian (To) age. The diachronous nature of the Slope Formation appears to be confirmed by a radiometric date near the base of the Bullion Creek Formation and the middle Tiffanian (Ti3) Brisbane mammalian local fauna. The Bullion Creek-Sentinel Butte formational contact is temporally well controlled on the basis of a number of low-diversity mammalian local faunas. Fort Union strata, as examined by F.V. Hayden in the middle 1800s, can now be restricted to the Ti3 and Ti4 ages. The age of the Sentinel Butte-Golden Valley formational contact is not well controlled. Floral similarities between the Bear Den Member and the Fort Union southeast of Red Lodge, Montana, suggest an early Clarkforkian age for the lower part of the Golden Valley Formation in North Dakota. The mammals, mollusks, and flora of the Camels Butte Member indicate a Wasatchian (Wa) age. The mammals from the White Butte Locality further suggest the Wa3 biochron.

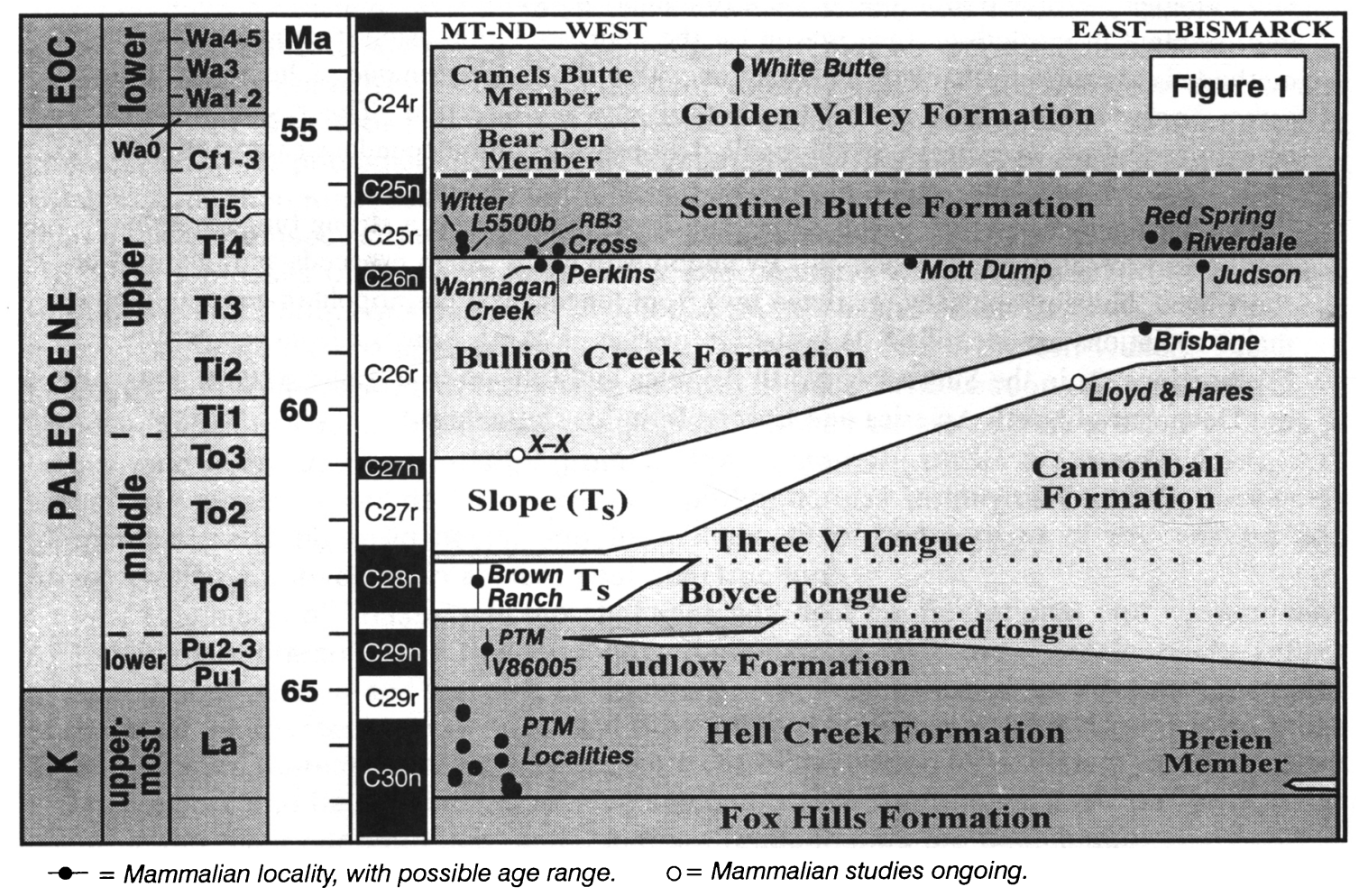

